\title{
肉豚枝肉の蓄積脂肋組織と筋肉組織の脂質の 脂肪酸組成の差異と相関
}

\author{
山内 清・那須裕二・大橋登美男・芳賀聖一 \\ 村田 寿・堀 元司 \\ 宮崎大学農学部, 宮崎市 889-21
}

(1989. 2. 6 受付)

\begin{abstract}
要 約本研究では, 南九州地域の異なった条件下で肥育され, 生体重 $105 \mathrm{~kg}$ で屠殺された 139 頭 の肉豚の枝肉加ら蓄積脂肪組織（背脂肪外層, $\mathrm{OBF}$; 背脂肪内屏, IBF; 腎臟周囲脂肪, $\mathrm{PF}$; 筇間脂 肪, IMF) および筋肉組織 (胸最長筋, M. longissimus thoracis, MLT) を採取し, 各喠組織脂質 相互間の脂肪酸組成の差異と相関を調べ, 併せて蓄積脂肪組織脂質から筋肉脂質の脂肪酸組成が推定で きるかどうかを検討した．各主要脂肪酸 $(16: 0,18: 0,18: 1,18: 2)$ 含量の割合は, 各種組織脂質間 で相違し，OBF，IBF および PF の間では有意に異なっていた。蓄積脂肪組織脂質相互間の主要脂肪 酸の相関係数の值は, OBF と IBF 間 $>\mathrm{IMF} と \mathrm{OBF}$ または $\mathrm{IBF}$ 間 $>\mathrm{IMF} と \mathrm{PF}$ 間 $>\mathrm{PF}$ と $\mathrm{OBF}$ または IBF 間の傾向にあった。この結果は，飼養条件のような外的要因の影響が PF と OBF または $\mathrm{IBF}$ 間の差異に最も強く反映されたが，OBF と IBF 間の各脂肪酸の固有の差異を变更しないことを 示唆した，蓄積脂肪組織脂質と筋肉脂質の間では，主要脂肪酸の相関係数は有意であったが，脂肪酸の 種類に依存してそれらの値は大きく变動し, また非常に低く, 特に $18: 0$ と $18: 1$ の両脂肪酸か顕著で あった．今回の結果は，蓄積脂肪組織脂質加筋肉脂質の脂肪酸組成を有意に高い相関係数の值を以っ て推定することが容易でないことを示した。
\end{abstract}

日畜会報, $60(8) ： 771-775,1989$

肉豚の蓄積脂肪および筋肉脂質の量的・質的性状が， 多くの内的および外的要因の影響を受けることは，数多 くの研究によって明らかである11. 大武”は，異なった 条件下で飼育され，市場に出荷されてきた肉豚枝肉につ いて，蓄積脂肪の脂質性状の蓄積部位間の差異および相 関を調べると同時に，督裁周囲脂肪（督脂）加ら筋肉の 脂肪の性質が推定できる可能性を報告した，しかし，大 武の結果では，その脂肪酸組成間の相関が必ずしも高く なかった，豚の場合，脂肪組織か脂肪酸合成の主要部位 とされ ${ }^{3}$ ，また外的要因，特に飼料脂質性状による影響 が，蓄積脂肪の部位間並びに蓄積脂肪と箭肉脂質間で大 きく相違することが知られている年出, 。これらの事実は， 異なった条件下で飼育され，市場に出荷された肉豚枝肉 の場合, ある特定の蓄積脂肪加ら筋肉脂質の脂肪酸組成 を高い相関関係をむって推定することが容易でないこと を示唆していると考えられる.

本研究では，蓄積脂肪から筋肉脂質の主要脂肪酸組成 の推定の可能性を再检討するため, 南九州地域の異なっ
だ条件下で肥育された肉豚枝肉の各種蓄積脂肪組織（背 脂肪の外層之内層, 筇間脂肪, 腎脂) 之筋肉組織（胸最 長筋) の脂質の脂肪酸組成並びにその相関関係を調べた.

\section{材料およびち法}

供試肉豚：供試肉豚は，前報 ${ }^{6)}$ と同一供試肉豚（LW 豚 55 頭， LWH 豚 84 頭）を用いた。すすなわち，肉豚 139 頭 (皁 66 頭, 来 73 頭) の枝肉加蓄積脂肪組織 （背脂肪外層，背脂肪内層，筋間脂肪，管脂）並びに筋 肉組織 (胸最長筋, M. longissimus thoracis) を採 取し，以下の分析に供した。しかし，一部の肉豚枝肉に ついては，同一個体からすべての組織を採取できなかっ た.

脂質の抽出・定量および脂肪酸の分析 : 各種組織の脂 質は，FoLCH らの方法 ${ }^{7)}$ に準じて抽出後，前報 ${ }^{6)}$ と同 様に脂質の定量および脂肪酸の分析を行なった。なお， 笳肉組織加抽出した総脂筫 (笳肉脂躓)の一部は， TERRELL らの方法 ${ }^{8)}$ に準じて中性脂質と㥛性脂質(主 
としてリン脂質）に分画し，両分画の脂肪酸組成も併せ て分析した.

\section{結果および考察}

\section{1. 蓄積脂肪および筋肉脂質の主要脂肪酸組成}

背脂肪外層 (以下 OBF 上略記), 背脂肪内層 (IBF), 腎脂 (PF)，筋間脂肪 (IMF) 並びに筋肉組織の総脂 質（MLT-TL）と中性脂質（MLT-NL）の主要脂肪 酸組成は，表 1 に示すとおりであった。

表 1 から明らかなように，主要脂肪酸，パルミチン酸 (16:0)，ステアリン酸 $(18: 0)$ ，オレイン酸 $(18: 1)$ およびリノール酸 (18:2) の合量は，IBF，PF および IMF が総脂肪酸の約 $95 \%$ を占め, OBF と MLT-NL が約 94\%，また MLT-TL が約 92\% を占めた. 他方, 筋肉組織の極性脂質 (MLT-PL) では，16:0 (21.0)， $18: 0$ (14.4)，18:1（14.0）お゙よび $18: 2(35.2 \%) の$ 合量が総脂肪酸の約 $85 \%$ を示し，またアラキドン酸 (20:4) が約 9\%を占めた。これら MLT-PL に対す る蓄積脂肪と MLT-NL の脂肪酸パターンの明らかな 差異については，すでによく知られている年2．
蓄積脂肪の脂肪酸組成は蓄積部位によって異なり，体 表層加ら体腔内に向かって飽和脂肪酸（SFA）の增加 と不飽和脂肪酸（USFA）の減少が明らかにされてい る゙が、この傾向は表 1 においてす認めることができる。 また，今回の PF の結果は，他蓄積脂肪に比べて $16: 0$ と $18: 0$ の両脂肪酸含量の割合が高く, $18: 1$ 含量が低 かったが，この事実は PF の特徴的な脂肪酸パターン゙) に一致するものであった，大武 ${ }^{2)}$ は，筋肉組織（臂筋） の NL 画分の脂肪酸パターンがPF に類似していたと 報告しているが，今回の MLT-NL は蓄積脂肪に比べ $\tau 18: 1$ 含量が高く, $18: 2$ 含量が低い NL の特徵的脂 肪酸パターン2,99 を示し, PF の脂肪酸パターンとの類 似性を認めることができなかった（表 1). また今回の MLT-NL の高 $18: 1$ 含量と低 $18: 2$ 含量の特徽は, MLT-TL 含量と $18: 1$ 含量 $(r=0.665, n=139)$ およ び $18: 2$ 含量 $(r=-0.830, n=139)$ との間の高い有意 な相関 $(\mathrm{P}<0.01)$ に反映した。ささきに, KocH ら 豚胸最長筋の総脂質（筋肉脂質）の脂肪酸パターンが OBF に類似していたことを示唆したが，今回の MLTTL の結果は, $18: 2$ と高度不跑和脂肪酸（PUFA）を

Table 1. The compositions of main fatty acids in lipids from the adipose tissues and skeletal muscle ( $M$. longissimus thoracis: MLT) of pork carcasses 1, 2, 3, 4

\begin{tabular}{|c|c|c|c|c|c|c|c|}
\hline \multirow{2}{*}{\multicolumn{2}{|c|}{ Fatty acids }} & \multicolumn{4}{|c|}{ Adipose tissues } & \multicolumn{2}{|c|}{ MLT } \\
\hline & & \multirow{2}{*}{$\begin{array}{l}\text { OBF } \\
(n=115) \\
\begin{array}{l}22.6^{\mathrm{A}} \\
(1.4)\end{array}\end{array}$} & \multirow{2}{*}{$\begin{array}{l}\text { IBF } \\
(\mathrm{n}=139) \\
\begin{array}{c}24.5^{\mathrm{Ba}} \\
(1.6)\end{array}\end{array}$} & \multirow{2}{*}{$\begin{array}{c}P F \\
(n=139) \\
\begin{array}{c}27.8^{C} \\
(1.5)\end{array}\end{array}$} & \multirow{2}{*}{$\begin{array}{c}\text { IMF } \\
(\mathrm{n}=109) \\
\begin{array}{l}25.7^{\mathrm{V}} \\
(1.5)\end{array}\end{array}$} & \multirow{2}{*}{$\begin{array}{c}\begin{array}{c}\text { Total } \\
\text { lipid } \\
(\mathrm{n}=139)\end{array} \\
\begin{array}{l}24.0^{\mathrm{E}} \\
(1.1)\end{array}\end{array}$} & \multirow{2}{*}{$\begin{array}{c}\begin{array}{c}\text { Neutral } \\
\text { lipid } \\
(\mathrm{n}=90)\end{array} \\
24.9^{\mathrm{Bb}} \\
(1.1)\end{array}$} \\
\hline Palmitic acid & $(16: 0)$ & & & & & & \\
\hline Stearic acid & $(18: 0)$ & $\begin{array}{l}11.9^{\mathrm{A}} \\
(1.6)\end{array}$ & $\begin{array}{l}15.4^{\mathrm{B}} \\
(1.9)\end{array}$ & $\begin{array}{l}19.6^{\mathrm{C}} \\
(1.9)\end{array}$ & $\begin{array}{l}15.5^{B} \\
(1.8)\end{array}$ & $\begin{array}{l}12.6^{\mathrm{D}} \\
(1.0)\end{array}$ & $\begin{array}{l}12.2^{\mathrm{A}} \\
(1.3)\end{array}$ \\
\hline Oleic acid & $(18: 1)$ & $\begin{array}{l}46.0^{\mathrm{Aa}} \\
(2.5)\end{array}$ & $\begin{array}{l}43.3^{\mathrm{B}} \\
(2.2)\end{array}$ & $\begin{array}{l}37.4^{\mathrm{C}} \\
(2.5)\end{array}$ & $\begin{array}{l}43.5^{\mathrm{B}} \\
(2.4)\end{array}$ & $\begin{array}{l}46.8^{A b} \\
(2.5)\end{array}$ & $\frac{52.1^{D}}{(2.1)}$ \\
\hline Linoleic acid & $(18: 2)$ & $\begin{array}{l}13.4^{\mathrm{A}} \\
(2.5)\end{array}$ & $\begin{array}{l}11.5^{\mathrm{B}} \\
(2.2)\end{array}$ & $\begin{array}{l}10.4^{\mathrm{C}} \\
(2.1)\end{array}$ & $\frac{10.1^{\mathrm{C}}}{(2.2)}$ & $\begin{array}{r}8.3^{D} \\
(2.0)\end{array}$ & $\begin{array}{r}4.3^{E} \\
(0.9)\end{array}$ \\
\hline SFA & & $\begin{array}{l}35.7^{\mathrm{A}} \\
(2.7)\end{array}$ & $\begin{array}{l}41.1^{\mathrm{B}} \\
(3.0)\end{array}$ & $\begin{array}{l}48.7^{\mathrm{C}} \\
(2.8)\end{array}$ & $\begin{array}{l}42.5^{D} \\
(2.9)\end{array}$ & $\begin{array}{l}37.8^{\mathrm{Ea}} \\
(1.9)\end{array}$ & $\begin{array}{l}38.4^{\mathrm{Eb}} \\
(2.0)\end{array}$ \\
\hline MUFA & & $\begin{array}{l}48.5^{A} \\
(2.8)\end{array}$ & $\begin{array}{l}45.4^{\mathrm{B}} \\
(2.5)\end{array}$ & $\begin{array}{l}39.4^{\mathrm{C}} \\
(2.6)\end{array}$ & $\begin{array}{l}45.7^{\mathrm{B}} \\
(2.6)\end{array}$ & $\begin{array}{l}50.1^{\mathrm{D}} \\
(2.8)\end{array}$ & $\begin{array}{l}55.7^{\mathrm{E}} \\
(2.3)\end{array}$ \\
\hline PUFA & & $\begin{array}{l}15.8^{\mathrm{A}} \\
(2.5)\end{array}$ & $\begin{array}{l}13.5^{\mathrm{B}} \\
(2.3)\end{array}$ & $\begin{array}{l}11.9^{\mathrm{c}} \\
(2.2)\end{array}$ & $\frac{11.8^{\mathrm{C}}}{(2.2)}$ & $\begin{array}{l}12.1^{\mathrm{c}} \\
(2.9)\end{array}$ & $\begin{array}{l}5.9^{\circ} \\
(1.2)\end{array}$ \\
\hline SFA/USFA & & $\begin{array}{c}0.56^{\mathrm{A}} \\
(0.07)\end{array}$ & $\begin{array}{r}0.70^{8} \\
(0.08)\end{array}$ & $\begin{array}{r}0.95^{\mathrm{c}} \\
(0.11)\end{array}$ & $\begin{array}{c}0.74^{\mathrm{D}} \\
(0.09)\end{array}$ & $\begin{array}{l}0.61^{\mathrm{Ea}} \\
(0.05)\end{array}$ & $\begin{array}{c}0.62^{\mathrm{Eb}} \\
(0.05)\end{array}$ \\
\hline
\end{tabular}

${ }^{1}$ Fatty acid compositions are expressed as weight percentages of total fatty acids and values given are means. ${ }^{2}$ Figures in parentheses show standard deviations. ${ }^{3}$ Values in the same row bearing the different large letter $(P<0.01)$ or the different small letter $(P<0.05)$ are significantly different from each other. ${ }^{4} \mathrm{OBF}, \mathrm{IBF}, \mathrm{PF}, \mathrm{IMF}, \mathrm{SFA}, \mathrm{MUFA}$, PUFA and SFA/USFA stand for outer layer of backfat, inner layer of backfat, perirenal fat, intermuscular fat, saturated fatty acids, monounsaturated fatty acids, polyunsaturated fatty acids and saturated fatty acids/unsaturated fatty acids, respectively. 


\section{蓄積脂質の差異と相関}

除いて，OBF に近似していた，IMF の脂肪酸パタ一 ンが皮下脂肪と PF の中間を示すことは，ウシ10) およ びヒッジ11でよく知られているが，WOOD らの肉豚の 結果 ${ }^{5)}$ では，このことを認めることができなかったしし かし，今回の IMF の脂肪酸パターンはIBF に近似し， また $\mathrm{OBF} と \mathrm{PF}$ の中問を示したことから, 肉豚の IBF の場合屯上述のウシ10)およびヒッジ11) と同じ傾向 にあることが示唆された。

\section{2. 各種組織脂質相互間の主要脂肪酸の相関}

蓄積脂肪および筋肉組織の脂質相互間の主要脂肪酸の 単純相関係数は，表 2 に示すとおりであった。

表 2 に示したょうに, OBF, IBF, PF おょび IMF の各種蓄積脂肪相互間では，主要脂肪酸の相関係数は $\mathrm{OBF}$ と IBF 閣で高い値を維持し，また両者間の各脂 肪酸の相関係数の檤の変動幅む最小であった。これらの 結果は, 大武”之一致していた。 次に, IMF と OBF または IBF 閪において高い相関係数を維持していたが， 各脂肪酸の相関係数の值の变動幅は $\mathrm{OBF}$ と $\mathrm{IBF}$ 間に 比べて增大する煩向にあった，脂肪酸パターンが近似し ていた IMF と IBF 間の值は, IMF と OBF 間に比べ て高く維持されていた（裴 $1 ， 2$ )，一方，PF 上他蓄積

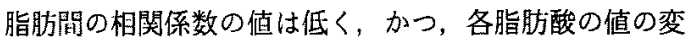
動幅が一層增大し，特に PF と OBF または IBF 間に

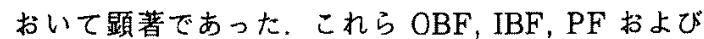
IMF の 4 者相互間において，16:0 と18:0の両脂肪酸 の相関係数の値が高く，18:1 $18: 2$ の值が低く維持 される傾向を示し，特に PF と OBF または IBF 間の 18:1の值の低下が顕著であった，そして，主要脂肪酸 の相関係数の值の変動は, SFA, MUFA, PUFA およ び SFA/USFA 比の值に淔接反映した（表 2)。また今 回の結果は, $\mathrm{OBF}$ と IBF 間>IMF と $\mathrm{OBF}$ または $\mathrm{IBF}$ 間 $>\mathrm{IMF}$ と $\mathrm{PF}$ 間 $>\mathrm{PF}$ と $\mathrm{OBF}$ または $\mathrm{IBF}$ 間 の順で，OBF と IBF 閣では各脂肪酸の相関係数值が 高く,このことは $\mathrm{OBF}$ と IBF 間の各脂肪酸の固有の 差異 ${ }^{12)}$ が諸要因によって大きく変更されないのに対し, $\mathrm{PF} と \mathrm{OBF}$ または IBF 問では影響の受けかたの差異 が最も大きいことを示唆した。

さらに，各種蓄積脂肪組織上筋肉組織の脂質間では， 各脂肪酸の相関係数値は有意であったが，上述の各種蓄 樍脂肪組織相互間の該当する各脂肪酸の值に比較して顕 著に低下し，筋肉組織のTL (MLT-TL) と NL (MLT-NL) の各脂肪酸の值の間にも相違が認められ， 特に TL では $18: 1$ に対する值が低下し，NLでは 18 ： 0の值が低下した（表2).しかし，予測されたように， MLT-TL ¿ MLT-NL 間の各脂肪酸は比較的高い相 関を維持していた．前述したように，大武2)は39 頭分

Table 2. Simple correlation coefficients for the mutual comparisons between the percentage concentrations of main fatty acids in the porcine adipose tissues lipids and muscle lipids ${ }^{\text {a }}$

\begin{tabular}{cccccccccc}
\hline \hline Comparison & & $16: 0$ & $18: 0$ & $18: 1$ & $18: 2$ & SFA & MUFA & PUFA & SFA/USFA \\
\hline OBF vs IBF & $(n=115)$ & 0.911 & 0.922 & 0.900 & 0.904 & 0.928 & 0.911 & 0.903 & 0.935 \\
vs PF & $(n=115)$ & 0.791 & 0.784 & 0.581 & 0.760 & 0.794 & 0.633 & 0.753 & 0.799 \\
vs IMF & $(n=109)$ & 0.870 & 0.885 & 0.816 & 0.847 & 0.890 & 0.812 & 0.815 & 0.891 \\
vs MLT-TLb & $(n=115)$ & 0.568 & 0.425 & 0.313 & 0.542 & 0.456 & 0.402 & 0.511 & 0.467 \\
vs MLT-NLc & $(n=90)$ & 0.594 & 0.352 & 0.473 & 0.615 & 0.406 & 0.544 & 0.611 & 0.421 \\
IBF vs PF & $(n=139)$ & 0.797 & 0.842 & 0.679 & 0.713 & 0.819 & 0.707 & 0.717 & 0.823 \\
vs IMF & $(n=109)$ & 0.923 & 0.884 & 0.829 & 0.884 & 0.913 & 0.820 & 0.836 & 0.914 \\
vs MLT-TL & $(n=139)$ & 0.522 & 0.518 & 0.270 & 0.512 & 0.560 & 0.342 & 0.502 & 0.566 \\
vs MLT-NL & $(n=90)$ & 0.637 & 0.409 & 0.428 & 0.499 & 0.469 & 0.515 & 0.559 & 0.471 \\
PF $\quad$ vs IMF & $(n=109)$ & 0.887 & 0.814 & 0.768 & 0.762 & 0.856 & 0.761 & 0.744 & 0.856 \\
vs MLT-TL & $(n=139)$ & 0.605 & 0.469 & 0.426 & 0.604 & 0.534 & 0.469 & 0.609 & 0.537 \\
vs MLT-NL & $(n=90)$ & 0.566 & 0.329 & 0.434 & 0.620 & 0.387 & 0.500 & 0.617 & 0.385 \\
IMF vs MLT-TL & $(n=109)$ & 0.626 & 0.614 & 0.308 & 0.576 & 0.659 & 0.315 & 0.588 & 0.667 \\
vs MLT-NL & $(n=90)$ & 0.689 & 0.474 & 0.469 & 0.557 & 0.626 & 0.473 & 0.542 & 0.628 \\
MLT-TL vs MLT-NL $(n=90)$ & 0.893 & 0.899 & 0.698 & 0.823 & 0.952 & 0.732 & 0.806 & 0.946 \\
\hline
\end{tabular}

${ }^{a}$ All the correlation coefficients given are significant at $\mathrm{P}<0.01$. Refer to Table 1 for meaning of abbreviations. ${ }^{b}$ Total lipid. ${ }^{\mathrm{c}}$ Neutral lipid. 
の肉豚枝肉を用いて，PF と繁筋の NL 間の主要脂肪 酸の相関を調べ, $16: 0(\mathrm{r}=0.72), 18: 0(\mathrm{r}=0.60)$, $18: 1(r=0.72), 18: 2(r=0.80)$, SFA $(r=0.59)$ および SFA/USFA $(\mathrm{r}=0.57)$ の相関係数值に基づい て，PF から NL の脂肪酸組成が推定できることを報 告した，今回得た $\mathrm{PF}$ 上 NL 間の各脂肪酸の相関につ いて，相対的に $18: 0$ の相関が弱く，18:2の相関が強 かった点は大武の結果 ${ }^{2)}$ と一致していたが，一般に相関 係数值は低く, PF から MLT-NL の脂肪酸組成を推 定することが容易でないことを示唆した。

肉豚の各種蓄積脂肪の脂肪酸組成への飼料脂質性状の 影響について, WoOD ら 脂肪に比較して PFに蓄積されやすいことを明らかに した。また KoCH らすも，飼料性 $18: 2$ が筋肉脂質に 比べて OBF，IBF，PF に容易に蓄積されたことを認め， それら蓄積脂肺の $18: 2$ 含量の增加に伴う他脂肪酸組成 への影㗽が，飽和脂肪酸に比べて $18: 1$ 含量の減少に強 く反映されたことから，蓄積脂肪の $18: 1$ 含量の変化は 飼料性 $18: 1$ 含量のみで説明できないとした。この18： 1 含量に対する影響要因の複秚さが，また，大武2”之今 回の結果で共通して認められた 18:1の相関の弱さに反 映されたものと推測される.

次に，䇽肉脂質と蓄積脂肪間では，前者が相対的に飼 料脂質性状の影響を受けにくく，また飽和脂肪酸レベル を一定に維持する傾向にあるとされている゙．筇肉組織 および蓄積脂肘組織の脂質合量の増加は，また，脂肪酸 組成の相逵に影響を及ぼした，䇟肉脂質の増加は，上述 したように, $16: 0(\mathrm{r}=0.476)$ と18:1 $(\mathrm{r}=0.665) の$ 増加並びに $18: 2(r=-0.830)$ の減少を生じ, 高い有 意な恫関を示したが, $18: 0$ との相関 $(\mathrm{r}=0.006, \mathrm{n}=$ 139）がほとんどなかった。他方，千国ら ${ }^{13)}$ は，蓄積脂 肪組織への脂肪蓄稫の增大に伴って 16:0の増加之 18 : 2の滅少を生じたが，18:0との関係は条件によって異 なりまた $18: 1$ との朋関が顕著に低く，有意でなかっ たことを朋らかにした。これらの事奏は，成熟肉豚の蓄 積脂肪之筋肉脂質間の各脂肪酸の相関係数值に大きく影 響し，今回の蓄積脂肪と MLT-NL 聞の $16: 0$ と18:2 におけ万高い相関並びに18:0と18：1における低い相 関に反咉したと考えられる。また各種組織の脂質含量の 相違は，脂肪蓄積の朋対速度に関係している可能性が考 えられるが，KEMPSTER ${ }^{14)}$ に上れば肉豚の脂肪蓄積の 朋対速度は蓄積部位によって相造し，督脂〉皮下脂肪〉
筋間脂肪>筋肉脂質の順であった，この脂肪蓄積の相対 速度の相違が，また，各脂肪酸の相関に影響を及ぼして いることが上述した干国らの結果 ${ }^{13)}$ より推測される.

今回の蓄皘脂肪組織相互間の結果より, 筋間脂肪の脂 肪酸組成を推定することは可能であると判断されるが, 一方, 蓄積脂肪組織から筋肉組織，すなわ筋肉脂質の 性状を推定することは，今回の両組織間の各脂肪酸の相 関が有意であったにもかかわらず，その相関係数の值が

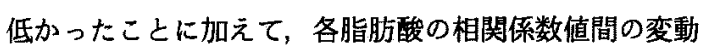
幅が大きかったため, 容易でないと結論づけられる。

\section{文献}

1) Pearson, A.M., J.D. Love and F.B. SHORLAND, Advances in Food Research, $23: 1$-74. 1977.

2）大武的之, 日畜会報，54:165-171. 1983.

3) O'Hea, E.K. and G.A. Leveille, J. Nutr., 99: 338-344. 1969.

4) Koch, D.E., A.M. Pearson, W.T. Magee, J.A. Hokfer and B.S. SChweigert, J. Animal Sci., $27:$ 360-365, 1967.

5) Wood, J.D., P.J. Buxton, F.M. WhitTingTON and M. ENSER, Livest. Prod. Sci., 15 : 73-82. 1986.

6）山内 清 - 大橋登美男 - 芳賀聖一・聞田利作 - 村 田寿・那須裕二, 日畜会報, $60: 166-171$. 1989.

7) Folch, J., M, LEE and G.H. SLOANEStanley, J. Biol. Chem., 226 : 497-509. 1957.

8) Terrell, R.N., G.G. Suess, R.G. Cassens and R.W. BrAY, J. Food Sci., 33 : 562-565. 1968.

9) Allen, E., R.G. Cassens and R.W. Bray, J. Animal Sci.: $26: 36-40.1967$.

10) Leat, W.M.F., J. Agric. Sci., $89: 575-582$. 1977.

11) Duncan, W.R.H. and G.A. Garton, J. Sci. Food Agric., 18 : 99-102. 1967.

12) KoCh, D.E., A.F. PARr and R.A. Merkel, J. Food Sci., $33:$ 176-180. 1968.

13）干国幸一・神野昌行・小沢 忍・小石川常吉・吉 武充・矢野信礼, 日豚研誌, $22: 181-187$. 1985.

14) Kempster, A.J., Meat Sci., 5 : 83-88. 198081. 


\title{
Fatty Acid Compositions of Lipids from Adipose Tissues and Muscular Tissue of Pork Carcasses and Their Differences and Correlations
}

\author{
Kiyoshi Yamauchi, Yuji Nasu, Tomio Ohashi, Seiichi Haga, \\ Hisashi Murata and Motoshi HorI \\ Faculty of Agriculture, Miyazaki University, \\ Miyazaki-shi $889-21$
}

The present study was performed with a total of 139 pork carcasses to elucidate the differences and correlation between the fatty acid compositions of adipose tissue lipids and muscle lipids. This included the possibility of readily estimating (with a significantly high correlation coefficient) the fatty acid composition of muscle lipids from adipose tissue lipids. The animals were raised under different conditions in the southern Kyushu area and slaughtered at about $105 \mathrm{~kg}$ live weight. Their adipose tissues (the outer layer of backfat, OBF ; the inner layer of backfat, IBF; perirenal fat, PF and intermuscular fat, IMF) and muscle ( $M$. longissimus thoracis, MLT) were excised and analyzed for their fatty acid compositions.

The percentage concentrations of each of the main fatty acids (palmitic acid, 16:0; stearic acid, 18:0; oleic acid, 18:1; linoleic acid, 18:2) varied among the tissue lipids evaluated. However, those between $\mathrm{OBF}, \mathrm{IBF}$ and PF were significantly different from each other. The simple correlation coefficient values for the percentage concentrations of main fatty acids between the adipose tissue lipids tended to decrease in the order of (between $\mathrm{OBF}$ and IBF) $>$ (between IMF and either $\mathrm{OBF}$ or IBF) $>$ (between IMF and PF) $>$ (between $\mathrm{PF}$ and either $\mathrm{OBF}$ or IBF). This suggests that the effects of extrinsic factors such as feeding conditions are most remarkably reflected in the differences in fatty acid compositions between $\mathrm{PF}$ and either $\mathrm{OBF}$ or IBF, whereas the respective intrinsic differences in the main fatty acids between OBF and IBF are unlikely to be affected by extrinsic factors. Between the adipose tissue lipids and muscle lipids simple correlation coefficients of their main fatty acids were found to be reduced and varied to a considerable extent. Although the values obtained were significant, they were very low depending upon the kind of fatty acid, particularly for both $18: 0$ and $18: 1$. The results demonstrated that there was considerable difficulty in estimating the fatty acid composition of muscle lipids from that for any adipose tissue lipids.

Jpn. J. Zootech. Sci., $60(8): 771-775,1989$

Key words : pork carcass, adipose tissue lipids, muscle lipids, fatty acid composition, correlation 